JURNAL NUANSA INFORMATIKA

Volume 12 Nomor 1, Januari 2018
p-ISSN : 1858-3911, e-ISSN : 2614-5405

https://journal.uniku.ac.id/index.php/ilkom

\title{
Implementasi Customer Relationship Management (CRM) Pada Penerimaan Siswa Baru (Studi Kasus di Pondok Pesantren Darussalam Kabupaten Garut)
}

\author{
Jajang Abdurrahman ${ }^{1}$, Dadang Hamdani ${ }^{2}$, Panji Novantara ${ }^{3}$ \\ Fakultas Ilmu Komputer Universitas Kuningan \\ Jl. Cut Nyak Dien No.36 A, Kel. Cijoho Kuningan 45513 \\ jajangrahman.jr@gmail.com ${ }^{1}$, dadanghamdani@uniku.ac.id ${ }^{2}$, \\ panjinovantara@uniku.ac.id ${ }^{3}$
}

\begin{abstract}
Abstrak - Dengan semakin ketatnya persaingan bidang pendidikan, khususnya rekrutmen peserta didik, maka pengelola lembaga sekolah dihadapkan pada upaya pengambilan keputusan yang tepat. Selain harus mempertahankan potensi peserta didik yang sudah ada, juga perlu adanya usaha untuk mendapatkan peserta didik baru melalui penerapan-penerapan strategi promosi sekolah yang tepat. Oleh karena itu, peningkatan kualitas layanan untuk memenangkan persaingan promosi sangat penting dilakukan.

Salah satu metode dalam peningkatan layanan menggunakan konsep manajemen hubungan dengan pelanggan atau Customer Relationship Management (CRM) yang merupakan strategi bisnis menyeluruh dari suatu perusahaan yang memungkinkan perusahaan tersebut secara efektif mengelola hubungan dengan para pelanggan, pada penelitian ini menggunakan Customer Relationship Management Operational (CRM Operasional). Sedangkan metode pengembangan sistem menggunakan metode Waterfall. Sistem yang dibangun berbasis web untuk memperluas penyebaran informasi pendaftaran siswa baru secara online, sehingga potensi untuk mendapatkan peserta didik baru, sistem yang dibangun berbasis web menggunakan bahasa pemograman PHP, database MySQL sebagai media penyimpanan data dan SMS Gateway sebagai penunjang sistem dalam mempermudah pelayanan terhadap siswa dan orang tua serta metode pengujian menggunakan black box \& white box testing. Sistem ini dapat digunakan oleh 4 hak akses yaitu Siswa, Orang Tua, Panitia PSB dan Ketua TMI.

Dengan bantuan teknologi komputer, Customer Relationship Management (CRM) menjadi sistem yang semakin berkembang dan lebih luas penggunaannya. Hal ini dikarenakan pemanfaatan CRM yang digunakan dengan baik akan menghasilkan keuntungan untuk mampu menjaga pelanggan dalam hal ini peserta didik yang sudah ada, menarik peserta didik baru, respon yang lebih cepat ke orang tua peserta didik, juga banyak manfaat lainnya.
\end{abstract}

Kata kunci: Pendaftaran Siswa Baru Online, Customer relationship management Operasional (CRM Operasional), Waterfall, Web.

Abstract - Along the tight competition in education field, especially the recruitment of students, the school manager faces problem in making right decision. In addition, to maintain the potential learners, it also needs an effort to get new learners through best strategies of school promotion. Therefore, improving service quality to win promotion competition is very important to do.

One of methods in improving service towards customer is customer relationship management (CRM), as a comprehensive business strategy of a company that enables the enterprise to manage customer relationships effectively, in this research, the writer uses Operational Customer Relationship Management. Whereas the method of system 
JURNAL NUANSA INFORMATIKA

Volume 12 Nomor 1, Januari 2018
p-ISSN : 1858-3911, e-ISSN : 2614-5405

https://journal.uniku.ac.id/index.php/ilkom

development used is Waterfall method.The system is built as a base Web to expand the spread of online new student enrollment information, so this programme is potentially to get new learners, the system was built as a web based, it uses PHP programming language and MySQL as data storage media and SMS Gateway as a support system in facilitating the students' and parents 'services, testing methods also used black box \& white box testing. This system can be used by 4 access, they are students, parents, New Students enrollment committee and head devision of TMI.

Using computer technology, Customer Relationship Management (CRM) is more developed and wider system because using CRM can keep the customers of the existing learners, the recruitment of new learners, the faster responses to learners' parents, and so on.

Keywords: Online New Student Registration, Customer Relationship Management (CRM) Operational, Waterfall, Web.

\section{PENDAHULUAN}

Pesatnya perkembangan teknologi informasi saat ini membuat manusia semakin memerlukan komputer dalam berbagai aktivitasnya. Keperluan tersebut mencakup berbagai aspek kebutuhan baik perorangan maupun instansi dan juga merambah ke berbagai bidang, seperti pendidikan, kesehatan, ekonomi, komunikasi, bisnis, hiburan dan lainnya. Dalam bidang pendidikan sendiri, saat ini telah begitu banyak yang memanfaatkan komputer dan internet untuk aplikasi online-nya. Dengan menggunakan aplikasi online tersebut jangkauan promosi akan lebih besar dengan biaya yang lebih rendah. Namun, dengan adanya kemudahan itu persaingan juga semakin tinggi.

Dengan semakin ketatnya persaingan bidang pendidikan, khususnya seleksi penerimaan siswa baru, maka pengelola lembaga sekolah dihadapkan pada upaya pengambilan keputusan yang tepat. Selain harus mempertahankan potensi peserta didik yang sudah ada, juga perlu adanya usaha untuk mendapatkan peserta didik baru melalui penerapan-penerapan strategi promosi sekolah yang tepat. Oleh karena itu, peningkatan kualitas layanan untuk memenangkan persaingan promosi sangat penting dilakukan.
Salah satu metode yang unggul dalam peningkatan layanan adalah dengan konsep manajemen hubungan dengan pelanggan atau Customer Relationship Management (CRM). CRM adalah sebuah strategi bisnis menyeluruh dari suatu perusahaan yang memungkinkan perusahaan tersebut secara efektif bisa mengelola hubungan dengan para pelanggan. CRM didukung oleh data konsumen yang berkualitas tinggi dan teknologi informasi. Secara konsep ada anggapan bahwa CRM merupakan sebuah proses pemasaran. Anggapantersebutbisa dianggap benar adanya, terutama bagi para praktisi dibidang pemasaran yang menganggap bahwa CRM adalah Customer Relationship Marketing. (Satria dan Mudjahidin, 2013: 76).

Dengan bantuan teknologi komputer, Customer Relationship Management (CRM) menjadi sistem yang semakin berkembang dan lebih luas penggunaannya. Hal ini dikarenakan pemanfaatan CRM yang digunakan dengan baik akan menghasilkan keuntungan untuk mampu menjaga pelanggan dalam hal ini peserta didik yang sudah ada, menarik peserta didik baru, respon yang lebih cepat ke orang tua peserta didik, juga banyak manfaat lainnya. 
JURNAL NUANSA INFORMATIKA

Volume 12 Nomor 1, Januari 2018

Salah satu lembaga pendidikan yang mempunyai misi meningkatkan pelayanan adalah Pondok Pesantren Darussalam yang terletak di Kampung Sindangsari, Desa Kersamanah, Kecamatan Cibatu, Kabupaten Garut, Provinsi Jawa Barat. Pondok pesantren tersebut menyelenggarakan pendidikan menengah, yaitu Sekolah Menengah Pertama (SMP) dan Sekolah Menengah Atas (SMA). Lembaga sekolah tersebut harus mampu berusaha untuk memberikan pelayanan yang baik, bukan sekedar memberikan ilmu pendidikan bagi para peserta didik, tapi juga menginginkan adanya peningkatan kuantitas peserta didik baru dari berbagai daerah di Indonesia dan loyalitas peserta didik lama.

Pada proses pendaftaran

Pondok Pesantren Darussalam saat ini harus melakukan pendaftaran secara langsung ke tempat,sehingga proses pendaftaran kurang begitu efektif. kurangnya pengetahuan siswa dalam mendapatkan informasi mengenai proses penerimaan siswa baru. Pada proses pencatatan data siswa atau pendaftaran masih menggunakan bantuan dari aplikasi Microsoft Excel atau Word, sehingga data siswa atau pendaftar sering terjadi kesalahan pada inputan dengan data yang sama. Pendaftaran dilakukan secara manual dengan mengisi form secara tertulis, sehingga mengakibatkan antrian yang panjang saat siswa melakukan pendaftaran.

Dengan adanya aplikasi CRM diharapkan dapat menangani permasalahan yang ada di Pondok Pesantren Darussalam, khusunya pada penerimaan siswa baru, serta penyebaran informasi mengenai penerimaan siswa baru dapat tersebar luas.

penulis $\begin{gathered}\text { Berdasarkan uraian di atas, } \\ \text { merasa }\end{gathered}$ tertarik untuk
p-ISSN : 1858-3911, e-ISSN : 2614-5405

https://journal.uniku.ac.id/index.php/ilkom

mengangkat masalah ini dengan melakukan penelitian untuk mendapatkan gambaran perancangan sistem.Sehingga sistem diharapkan nantinya dapat bermanfaat dan digunakan semaksimal mungkin.Semua rumusan-rumusan dan analisa, penulis tuangkan dalam suatu tulisan dalam bentuk skripsi dengan judul "Implementasi Customer Relationship Management (CRM) pada Penerimaan Siswa Baru (Studi Kasus di Pondok Pesantren Darussalam Kabupaten Garut)".

\section{METODE PENELITIAN}

Metode penelitian yang digunakan dalam penulisan skripsi ini adalah sebagai berikut:

\subsection{Metode Pengumpulan Data}

Adapun metode pengumpulan data yang penulis lakukan untuk kelancaran dan kemudahan dalam penulisan penelitian ini adalah sebagai berikut :

\section{Wawancara}

Untuk mendapatkan data dan informasi yang berhubungan dengan sistem informasi yang dibutuhkan, dilakukan wawancara langsung dengan Bapak Kiyai Cecep Ishaq Ash'ari Mu'tie selaku pimpinan dan kepada Pak Joko Waluyo, S.Pd.I selaku Ketua TMI

\section{Studi Pustaka}

Penulis mengumpulkan datadata yang menjadi referensi dari buku, internet, maupun jurnal sebagai yang terkait dengan topik penelitian untuk bahan acuan dalam penyelesaian penelitian ini.

\subsection{Metode Pengembangan Perangkat Lunak}

Model pengembangan sistem yang digunakan dalam pengembangan sistem ini menggunakan model 
JURNAL NUANSA INFORMATIKA

Volume 12 Nomor 1, Januari 2018

Waterfall. Model waterfall merupakan model klasik sederhana dengan aliran sistem yang linier. Dalam membangun aplikasi ini, model waterfall sangat cocok dikarenakan keterkaitan dan pengaruh antar tahap ini terasa, karena output sebuah tahapan dalam model waterfall merupakan input bagi tahap selanjutnya, dengan demikian ketidaksempurnaan hasil pelaksanaan tahap sebelumnya adalah awal ketidaksempurnaan bagi tahap selanjutmya. Adapun gambaran utama dan langkah-langkah penelitian berdasarkan model waterfall adalah :

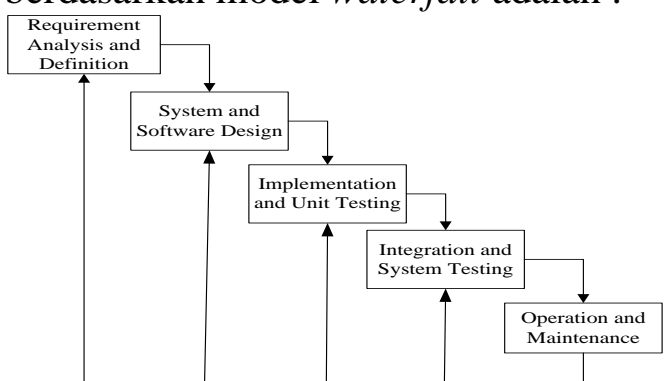

Gambar.1 Model Waterfall

Tahapan-tahapan yang harus dilakukan pada saat pelaksanaan pengembangan dalam metode ini adalah sebagai berikut:

\section{Requirement Analysis and} Definition

Mengumpulkan kebutuhan secara lengkap kemudian di analisis dan di definisikan kebutuhan yang harus dipenuhi oleh program yang akan dibangun. Pada tahapan pertama, penulis mengumpulkan data-data yang dibutuhkan guna menunjang dalam pembuatan sistem yang di usulkan. Data tersebut penulis peroleh melalui proses studi pustaka serta dengan melakukan observasi dan wawancara kepada narsumber yaitu pemilik atau karyawan pada beberapa lapangan futsal di Kabupaten Kuningan jawa barat.

\section{System and Software Design}

Pada tahapan kedua, penulis melakukan persiapan rancang bangun
p-ISSN : 1858-3911, e-ISSN : 2614-5405

https://journal.uniku.ac.id/index.php/ilkom

implementasi yang menggambarkan bagaimana suatu sistem dibentuk. Penulis mendesain perancangan sistem mulai dari Flowmap, Context Diagram, Data Flow Diagram (DFD), Entity Relationship Diagram (ERD) dan sebagainya.

\section{Implementation and Unit Testing}

Pada tahapan ini, penulis melakukan terjemahan dari desain program yang telah dilakukan pada tahap sebelumnya kedalam kode - kode dengan menggunakan bahasa pemrograman yang sudah ditentukan, yakni PHP dengan database MySQL.

\section{Integration and System Testing}

Unit program diintregasikan dan diuji menjadi sistem yang lengkap untuk meyakinkan bahwa persyaratan perangkat lunak telah dipenuhi. Dan melakukan percobaan dari software (perangkat lunak) atau aplikasi yang telah dibuat dan memperbaiki apabila masih terdapat kesalahan. Pada tahap ini, penulis akan melakukan pengujian sistemdengan menggunakan Black Box dan White Box Testing.

\section{Operation and Maintenance}

Perangkat lunak yang telah dibuat dan dikirim ke user tidak menutup kemungkinan mengalami perubahan. Perubahan bisa terjadi karena adanya kesalahan yang muncul dan tidak terdeteksi saat pengujian atau perangkat lunak harus beradaptasi dengan lingkungan baru. Oleh karena itu pada tahapan ini melakukan pemeliharaan perangkat lunak yang mengalami perubahan agar dapat berjalan dan sesuai dengan yang dirancang.

\section{HASIL DAN PEMBAHASAN \\ 3.1 Sistem yang Sedang Berjalan}


JURNAL NUANSA INFORMATIKA

Volume 12 Nomor 1, Januari 2018

Dokumen-dokumen dan catatan yang sedang digunakan Pondok Pesantren Darussalam digambarkan dengan flowmap yang dapat dilihat pada gambar berikut ini:

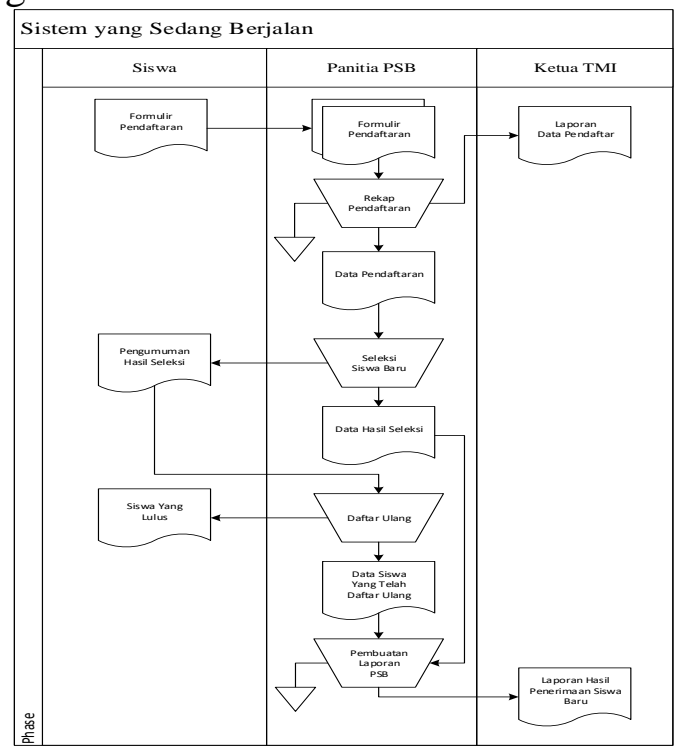

Gambar.2 Sistem yang Sedang Berjalan

\subsection{Sistem yang Diusulkan}

Dengan dibangunnya sistem baru ini, proses pendaftaram pada Pondok Pesantren Darussalam tidak hanya dilakukan di tempat tersebut berada, tetapi dapat dilakukan secara online, dimana pelanggan dapat langsung mengakses ke alamat website yang disediakan oleh Pondok Pesantren Darussalam. Sehingga tidak hanya dapat menjangkau calon siswa yang berada dekat dengan Pondok Pesantren tetapi dapat mejangkau calon siswa di luar daerah.

Selain itu dengan dibangunnya sistem ini, dapat mempermudah kepada calon siswa yang akan mendaftar ke Pondok Pesantren Darussalam dimanapun berada karena pendaftarannya pun sangatlah mudah. Oleh karena itu, informasi yang dihasilkan akan lebih cepat dan akurat serta tidak akan sulit ataupun memerlukan waktu yang lama dalam melakukan proses pendaftaran.
p-ISSN : 1858-3911, e-ISSN : 2614-5405

https://journal.uniku.ac.id/index.php/ilkom

Rancangan sistem yang di usulkan akan digambarkan dengan flowmap yang dapat dilihat pada gambar dibawah ini:

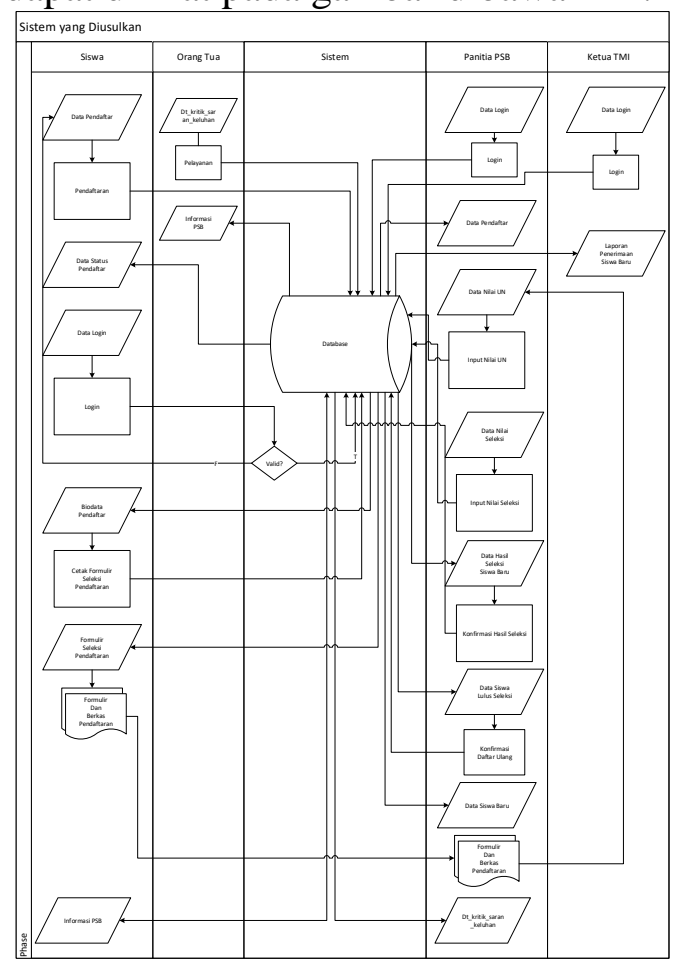

Gambar.3 Sistem yang Diusulkan

\subsection{Diagram Konteks}

Diagram konteks digunakan untuk menggambarkan sistem secara umum. Diagram konteks merupakan level tertinggi dari DFD yang menggambarkan seluruh input kedalam sistem dan output dari sistem.

Gambaran diagram konteks dari sistem penerimaan siswa baru yang akan dibuat dapat dilihat pada gambar berikut:

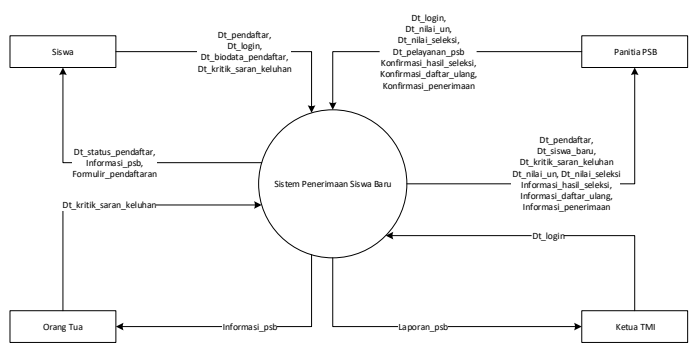

Gambar.4 Diagram Konteks 
JURNAL NUANSA INFORMATIKA

Volume 12 Nomor 1, Januari 2018

\subsection{Data Flow Diagram}

Data Flow Diagram digunakan untuk menggambarkan

keseluruhan

komponen sistem yang saling berhubungan sesuai aturan. Dibawah ini adalah DFD dari sistem penerimaan siswa baru di Pondok Pesantren Darussalam yang akan dibuat dapat dilihat pada gambar berikut :

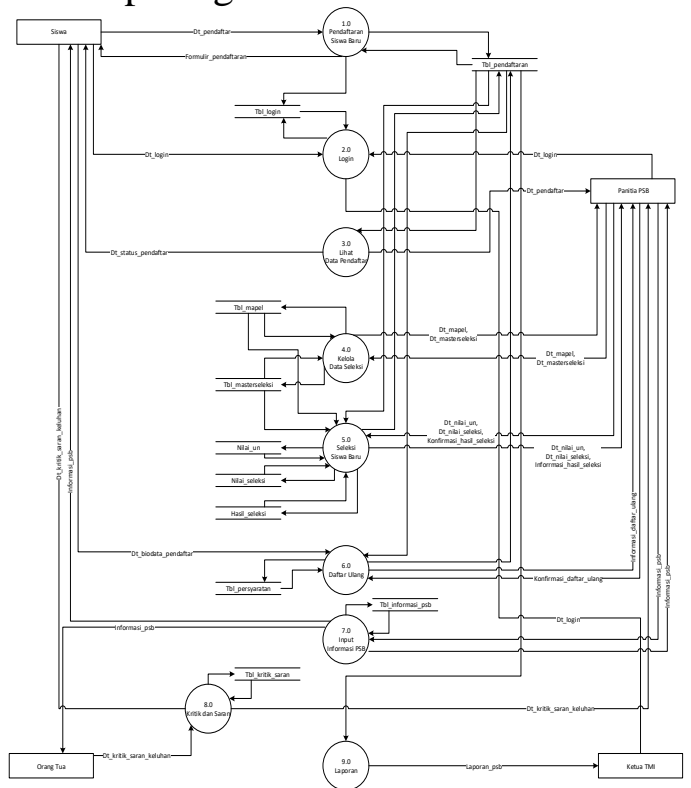

Gambar.5 Data Flow Diagram

3.5 Data Flow Diagram Level 1 Proses Seleksi Siswa Baru

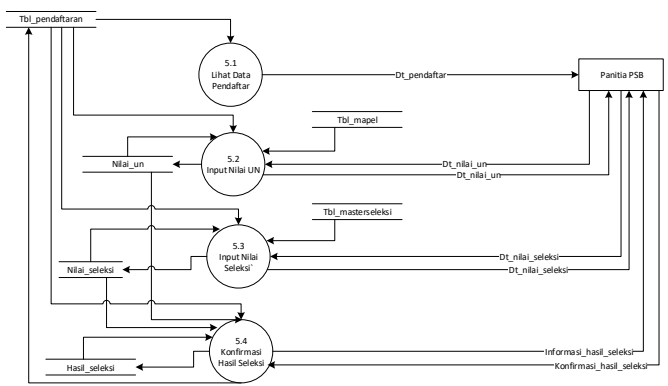

Gambar.6 Data Flow Diagram Level 1

\subsection{Entity Relationship Diagram (ERD)}

Entity Relationship Diagram (ERD) digunakan untuk memodelkan kebutuhan data dari perancangan program sistem penjualan dan pemesanan online pada Toko Utami, serta memberikan dasar untuk desain database relasional yang mendasari
p-ISSN : 1858-3911, e-ISSN : 2614-5405

https://journal.uniku.ac.id/index.php/ilkom

sistem yang dikembangkan. ERD pada Pendaftaran Siswa Baru Pondok Pesantren Darussalam dapat dilihat di gambar berikut

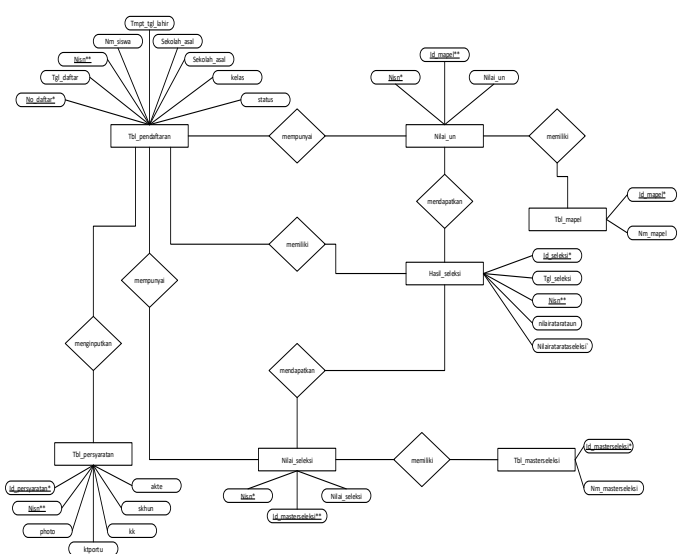

\section{Gamabr.7 Entity Relationship Diagram (ERD)}

\subsection{Relasi Antar Tabel}

Dalam suatu perancangan, tabel memiliki beberapa keterakaitan antar tabel atau dengan yang lainnya, maka digunakan relasi antar tabel untuk memperjelas hubungan tersebut. Adapun gambaran dari bentuk relasinya dapat dilihat pada gambar berikut:

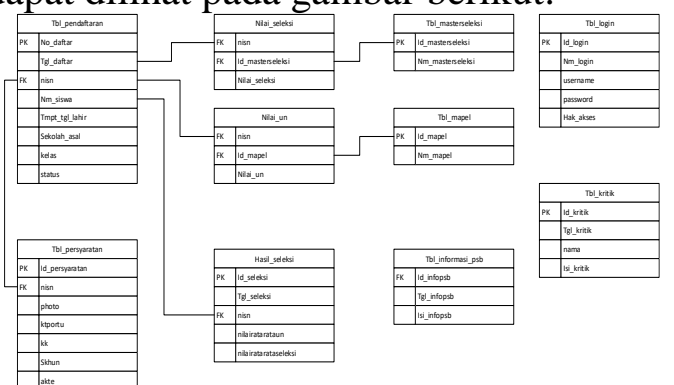

Gambar.8 Relasi Antar Tabel

\subsection{Implementasi Antarmuka}

Di dalam implementasi antar muka ini hanya menerangkan mengenai kegunaan form-form yang ada di dalam Implementasi Customer Relationship Management (CRM) pada Penerimaan Siswa Baru.

\subsubsection{Halaman Utama}

Halaman menu utama merupakan tampilan awal dari sistem, didalam halaman utama terdapat menu-menu 
JURNAL NUANSA INFORMATIKA

Volume 12 Nomor 1, Januari 2018

sesuai hak akses user yang dapat memberikan kemudahan dalam melakukan proses pengolahan data pada sistem. Untuk lebih jelasnya dapat dilihat pada gambar berikut:

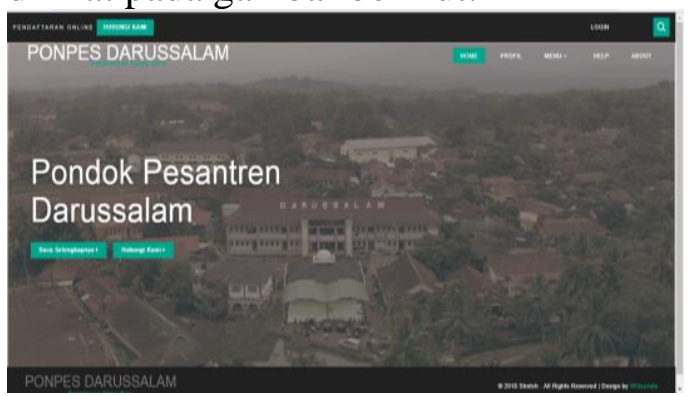

Gambar.9 Halaman Utama

3.8.1.2 Halaman Input Nilai UN dan Nilai Seleksi Halaman Input Nilai UN dan Nilai Seleksi merupakan halaman yang berfungsi untuk menginputkan Nilai UN dan Nilai Seleksi dari masingmasing siswa yang telah melakukan pendaftaran. Untuk lebih jelasnya dapat dilihat pada dibawah ini.

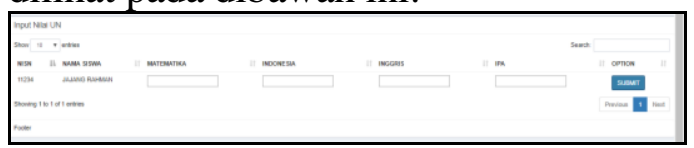

Gambar.10 Halaman Input Nilai

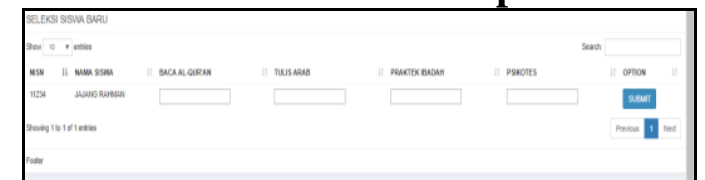

Gambar.11 Halaman Input Nilai Seleksi

\subsubsection{Halaman Hasil Seleksi}

Halaman Hasil Seleksi merupakan halaman yang menampilkan informasi dari hasil Input Nilai UN dan Input Nilai Seleksi. Informasi tersebut akan diolah lagi untuk menentukan siswa tersebut lulus seleksi ataupun tidak dengan menekan salah satu aksi Lanjut ataupun Tidak Lanjut. Untuk lebih jelasnya dapat dilihat pada gambar berikut:

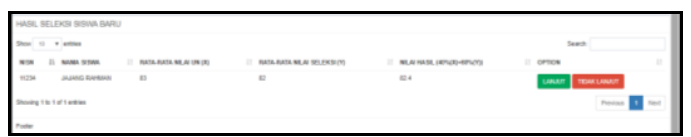

Gambar.12 Halaman Hasil Seleksi
p-ISSN : 1858-3911, e-ISSN : 2614-5405

https://journal.uniku.ac.id/index.php/ilkom

\section{KESIMPULAN}

Adapun kesimpulan yang diperoleh dari hasil penelitian skripsi ini adalah sebagai berikut :

1. Sistem yang dibangun mempermudah bagi Siswa dalam melakukan pendaftaran dan Panitia dalam melakukan proses seleksi pada Penerimaan Siswa Baru di Pondok Pesantren Darussalam Kabupaten Garut.

2. Dengan mengimplementasikan Customer Relationship Management (CRM) pada Penerimaan Siswa Baru di Pondok Pesantren Darussalam Kabupaten Garut menjadi lebih efektif dan efisien.

3. Dengan mengimplementasikan Customer Relationship Management (CRM) pada Penerimaan Siswa Baru di Pondok Pesantren Darussalam Kabupaten Garut dapat mempermudah, mempercepat pada penerimaan siswa baru, sehingga lebih akurat dan lebih tepat sasaran.

\section{SARAN}

Dalam penyusunan skripsi ini penulis menyadari masih banyak terdapat kekurangan. Adapun saran-saran yang dapat diberikan yaitu :

1. Aplikasi yang telah dibangun masih dapat dikembangkan sekaligus menjadi CRM Operasional, CRM Analisis, dan CRM Kolaboratip;

2. Dalam pembuatan aplikasi ini masih banyak sekali kekurangan, oleh karena itu diperlukan adanya pengembangan yang lebih lanjut bagi peneliti berikutnya.

\section{DAFTAR PUSTAKA}

[1]. Mudjahidin, Nyoman Dita Pahang Putra. Rancang Bangun Sistem Informasi Monitoring Perkembangan Proyek Berbasis Web Studi Kasus Di Dinas Bina 
JURNAL NUANSA INFORMATIKA

Volume 12 Nomor 1, Januari 2018

Marga Dan Pemantusan. Jurnal Teknik Industri, Vol. 11, No. 1, Februari 2013: 76

[2]. Amin Widjaja Tunggal, 2000, Auditing Suatu Pengantar, Jakarta: Penerbit Rineka Cipta. A.S Rosa dan Salahuddin M, 2011. Modul Pembelajaran Rekayasa Perangkat Lunak (Terstruktur dan Berorientasi Objek), Modula, Bandung.

[3]. Al-Bahra bin Ladjamudin. 2005. Analisis dan Desain Sistem Informasi. Yogyakarta : Graha ilmu

[4]. Nurdin Usman, 2002, Konteks implementasi berbasis Kurikulum, Bandung, CV Sinar Baru. Guntur Setiawan. (2004). Implementasi Dalam Birokrasi Pembangunan. Bandung: Remaja Rosdakarya offset.Jaya, Putra (2013). Sistem Pendukung Keputusan Penentuan Bonus Karyawan Menggunakan Metode Weight Product (WP). Pelita Informatika Budi Darma, Vol. V, No. 2, diunduh pada 26 Maret 2017

[5]. Kotler, Philip dan Kevin Lane Keller, (2006), Marketing Management, Pearson Education Inc.

[6]. Kotler, Philip and Gary Armstrong. 2008. Prinsip-prinsip Pemasaran. Edisi 12. Jilid 1.Jakarta: Erlangga.

[7]. Jill Dyche. 2002. The CRM Hand Book : A Business Guide to Customer Relationship Management.

[8]. Atmaja, Lukas Setia. 2001. Manajemen Keuangan. Edisi kedua. Cetakan kedua. Yogyakarta: ANDI.

[9]. Tjiptono, Fandy. 2007. Strategi Pemasaran. Edisi Kedua. Yogyakarta : Andi.
p-ISSN : 1858-3911, e-ISSN : 2614-5405

https://journal.uniku.ac.id/index.php/ilkom

[10]. Ade Paul, Lukas, 2001, Makalah Seminar : Customer and Partner Relationship Management, Telematic Research Group.

[11]. Atmaja, Lukas Setia. 2001. Manajemen Keuangan. Yogyakarta: ANDI.

[12]. Greenberg, N.S. (2002). Comprehensive stress management. $7^{\text {th }}$ ed. New York : Mc Graw- Hill companies, Inc.

[13]. Beck, B. Summer, J. 2001. Data Warehousing Horizons: CRM: Not Just Operational and Collaborative.

[14]. Ellislab,inc.(n.d.).userguide.Retrie ved

23,2013,fromhttp://ellislab.com/c odeigniter:

http://ellislab.com/codeigniter/use $r$-guide/

[15]. Fauziah dan Novianti. 2009. Sistem Informasi Sekolah Dasar Berbasis SMS. Yogyakarta: Universitas Islam Indonesia, Seminar Nasional Aplikasi Teknologi Informasi 2009, ISSN: 1907-5022.

[16]. Fikri, Azkal. 2010. Aplikasi Short Message Service (SMS) Gateway Untuk Layanan Informasi Registrasi Administrasi Mahasiswa. Jurnal. Universitas Pendidikan Indonesia. 